\title{
Kindergarten pre-reading skills predict Grade 9 reading comprehension (PISA Reading) but fail to explain gender difference
}

\author{
Mari Manu $^{1}$ (D) Minna Torppa ${ }^{1}$ (D) $\cdot$ Kenneth Eklund ${ }^{2}$ (D) \\ Anna-Maija Poikkeus ${ }^{1}$ D $\cdot$ Marja-Kristiina Lerkkanen ${ }^{1}$ (D) Pekka Niemi ${ }^{3}$
}

Accepted: 30 August 2020 / Published online: 10 September 2020

(c) The Author(s) 2020

\begin{abstract}
One of the aims for compulsory education is to diminish or alleviate differences in children's skills existing prior to school entry. However, a growing gender gap in reading development has increasingly been documented. Regrettably, there is scant evidence on whether differences between genders (favouring girls) have their roots in pre-reading skills or whether determining mechanisms are related to factors to do with schooling. We examined the extent to which pre-reading skills assessed in Kindergarten (age 6) predict reading comprehension in Grade 9 (age 15) and, whether the gender difference in reading comprehension can be explained by gender differences in the Kindergarten pre-reading skills. A sample of 1010 Finnish children were assessed on letter knowledge, phonological awareness, rapid naming, vocabulary, and listening comprehension in Kindergarten and on reading comprehension using PISA Reading tasks in Grade 9. Path models showed that gender as well as Kindergarten pre-reading skills except for phonological awareness were significant predictors of reading comprehension in Grade 9 accounting for $28 \%$ of the variance. There were gender differences in most of the measures, but the prediction model estimates were similar for boys and girls except that for boys, letter knowledge was a somewhat stronger predictor of reading comprehension than for girls. The gender effect on reading comprehension was only partially mediated via pre-reading skills. The findings suggest that Kindergarten pre-reading skills are powerful predictors of reading comprehension in Grade 9, but the gender difference found in PISA Reading in Finland does not appear to be pronounced in Kindergarten but rather emerges during the school years.
\end{abstract}

Keywords Gender differences · PISA Reading · Pre-reading skills · Reading comprehension

Minna Torppa

minna.p.torppa@jyu.fi

Extended author information available on the last page of the article 


\section{Introduction}

In order to become a competent citizen of the society and to acquire the necessary skills for full civic participation, one needs to be able to read and comprehend different types of texts. The PISA (The Programme for International Student Assessment) studies with 15-year-old Finnish students have shown a high level of reading performance compared to their peers in other countries (The Organisation for Economic Co-operation and Development [OECD], 2014). Despite the high ranking of Finnish youth's PISA performance, a worrying proportion of up to $11 \%$ of Finnish 15 -yearolds is estimated to fail to achieve the level of reading skills commended for being able to be proficient in education and society (Vettenranta et al., 2016). To target these students for early support, it is important to identify the factors and developmental mechanisms contributing to their less than optimal reading development. In the present study, we use Kindergarten (age 6) data to predict adolescent reading comprehension in Grade 9 (age 15). We draw on the comprehensive, widely used reading comprehension test from the PISA Reading test battery developed in association with the comparative assessments managed by OECD (2016). Although the status of this assessment tool of 15-year-old students' reading comprehension and its impact on educational policymaking are widely acknowledged, the research concerning pre-reading skills, predictors and correlates of the PISA Reading, however, is still surprisingly scarce internationally.

In addition to early identification, this paper has a focus on gender differences. The Finnish 15-year-olds manifest a gender difference in reading comprehension which is the largest among OECD countries and the ninth largest among all participating countries in PISA Reading (Brozo et al., 2014; OECD, 2016). In general, the proposed explanations for relatively large gender differences in reading skills favouring girls include school-age individual factors such as an interest in and the extent of leisure reading, or factors related to the school such as "girl-friendly school practices" (see Stoet \& Geary, 2013). There is evidence, however, pointing at potential early roots of these differences as some studies have shown that girls outperform boys in language and cognitive skills already before school entry (Lange, Euler, \& Zaretsky, 2016; Palejwala \& Fine, 2015). These findings lead us to examine whether the gender difference in 15-year-olds' PISA Reading performance can be explained by differences in pre-reading skills between girls and boys that emerge already prior to school entry.

\section{Early predictors of reading comprehension}

According to the Simple View of Reading (Florit \& Cain, 2011; Gough \& Tunmer, 1986; Hoover \& Gough, 1990; Kirby \& Savage, 2008), comprehension of written text presupposes, first, learning to decode-that is, acquiring the ability to decipher letter strings to words that appear in spoken language and, second, proficiency in linguistic comprehension. The relative importance of these two components, decoding and comprehension, changes across reading development. When 
decoding is not yet fully automatized, it has a stronger impact on reading comprehension than later when a sufficient decoding ability has been achieved (e.g., Florit \& Cain, 2011). Once decoding becomes fluent enough, linguistic comprehension displays a more prominent role than decoding in determining the level of reading comprehension skills (e.g., Perfetti, 1985). Despite this diminishing trend for the predictive role of decoding across age, reading fluency continues to have a significant role in adolescent PISA Reading in Grade 9, explaining 8-15\% of the variance in the PISA score (Artelt, Schiefele, \& Schneider, 2001; Eklund, Torppa, Sulkunen, Niemi, \& Ahonen, 2018; Torppa, Eklund, Sulkunen, Niemi, \& Ahonen, 2018). In the analysis of Kindergarten predictors of PISA Reading, we thus need to include measures of both linguistic comprehension and the known predictors of decoding and reading fluency.

The key early predictors of decoding and reading fluency among Finnish children and adolescents have repeatedly been reported to include letter knowledge, phonological awareness, and rapid naming (e.g., Kairaluoma, Torppa, Westerholm, Ahonen, \& Aro, 2013; Puolakanaho et al., 2007; Torppa, Eklund, van Bergen, \& Lyytinen, 2015). Similar findings have been found in other languages (e.g., Elbro, Borstrøm, \& Petersen, 1998; Gallagher, Frith, \& Snowling, 2000; Ziegler et al., 2010). However, studies in transparent orthographies such as Finnish, suggest that the association between phonological awareness and reading fluency gets weaker after Grades 1 or 2 whereas in less transparent orthographies the association remains stronger (de Jong \& van der Leij, 2002; Landerl \& Wimmer, 2000; Torppa et al., 2015). After the acquisition of basic decoding skills, individual differences in reading performance are primarily seen in speed as opposed to accuracy of decoding (e.g., Bekebrede, van der Leij, \& Share, 2009). Kindergarten rapid naming is a strong predictor of reading fluency (e.g., Georgiou, Parrila, \& Papadopoulos, 2008; Savage \& Frederickson, 2005) and in transparent orthographies it is one of the most powerful predictors of reading skill already in the early grades (e.g., Puolakanaho et al., 2007). This applies to Finnish because of its almost perfect grapheme-to-phoneme correspondence which contributes to fast reading acquisition (Aro, 2017). More than 95\% of Finnish children are accurate decoders after a few months of reading instruction in Grade 1 (Holopainen, Ahonen, \& Lyytinen, 2001; Lerkkanen, Rasku-Puttonen, Aunola, \& Nurmi, 2004).

As Finnish children on average become relatively fluent readers early in their schooling, the listening comprehension skills rather than decoding accuracy explain a growing portion of individual differences in reading comprehension in elementary grades (Dufva, Niemi, \& Voeten, 2001; Eklund et al., 2018; Lerkkanen et al., 2004). In their SVR model, Gough and Tunmer (1986) suggested that measures of listening comprehension can preferably be used to assess linguistic comprehension, but later research has shown that vocabulary measures are reliable predictors of reading comprehension as well (e.g., Cain, Oakhill, \& Bryant, 2004; Manolitsis, Georgiou, \& Parrila, 2011; Ouellette, 2006; Torppa et al., 2006). Weak vocabulary knowledge can form a bottleneck particularly when reading comprehension requires comprehending complex words in order to make inferences (Cain, 2016). 


\section{Pre-reading skills as predictors of PISA Reading comprehension}

The PISA Reading test, the outcome measure of the present study, assesses comprehension of various genres such as texts, tables, and graphs. It thus includes a broader array of tasks than many commonly used reading comprehension assessments that typically involve only continuous texts. PISA Reading tasks aim to test skills essential for full participation in modern societies (OECD, 2017a). The test protocol (OECD , 2017b, 51) uses the term Reading Literacy to indicate the broad coverage of the test assessing "understanding, using, reflecting on and engaging with written texts, in order to achieve one's goals, to develop one's knowledge and potential, and to participate in society." The test (containing always a certain number of repeated link items to retain comparability between reading scores from different years) is used every three years in the comparative assessments of educational quality.

Research on skills predicting PISA Reading is scarce. Arnbak (2012) showed that concurrently measured word recognition and vocabulary explained $41 \%$ of the PISA Reading scores among Danish students, whereas Artelt et al. (2001) reported that concurrently measured decoding speed explained $13 \%$ of the variance in PISA Reading among German students. Using another Finnish sample than in the current study, Torppa et al. (2018) reported that concurrently assessed reading fluency predicted up to $15 \%$ of the variance in PISA Reading among Finnish students. To our knowledge, there is only one longitudinal study that has examined early predictors of PISA Reading, that by Eklund et al. (2018) involving a sample of adolescents with family risk for dyslexia $(n=88)$ and another sample without family risk for dyslexia $(n=70)$. The results showed that oral language skills (e.g., vocabulary) assessed prior to school entry predicted 53\% of the PISA Reading variance among the high-risk group and $31 \%$ among the low-risk group. The pre-reading predictors of decoding (phonological awareness, rapid naming, letter knowledge) predicted 15\% of the PISA Reading variance among the high-risk group and $13 \%$ among the low-risk group via reading fluency. The samples in the study by Eklund et al. were, however, relatively small.

\section{Gender differences in pre-reading skills and PISA Reading}

Gender differences in reading favouring girls is a robust finding across languages (e.g., OECD, 2014) as well as the overrepresentation of boys among struggling readers (e.g., Quinn \& Wagner, 2015), often found already for young readers (for a recent meta-analysis, see Quinn, 2018). In PISA 2015, for instance, girls outperformed boys in reading comprehension in every participating country (OECD, 2016) although the size of the gender gap in reading varies considerably between countries (OECD, 2010a). Among Finnish students, it has been reported to be relatively large with a medium effect size (Cohen's $d=.50$, OECD, 2016) making Finland belong to the group of the participating countries with a pronounced gender difference (Brozo et al., 2014; OECD, 2016). In 2015, Finnish girls outperformed girls from other countries and scored best in PISA Reading (551 points) while Finnish boys ranked seventh (504 points) among boys from other countries (Vettenranta et al., 2016). 
Although also Finnish boys performed relatively well, the difference of 47 points is estimated to correspond to a one-year gap in the mastery of the basic education syllabus (Vettenranta et al., 2016). In PISA Reading, there are seven levels of reading proficiency (OECD, 2017b). In 2015, 16\% of Finnish boys and 7\% of Finnish girls did not achieve Level 2, which one should reach to be able for active participation in an information society (Vettenranta et al., 2016).

However, the literature is equivocal with respect to gender differences in reading skills and difficulties, because there are also studies showing no clear gender differences in reading skills and reading motivation (e.g., McGeown, Goodwin, Henderson, \& Wright, 2012), or in the occurrence of reading difficulties (e.g., Jimenez et al., 2011; Moll, Kunze, Neuhoff, Bruder, \& Schulte-Körne, 2014). Moreover, in a longitudinal study using another Finnish sample, no differences in terms of reading difficulties were found between boys and girls in Grade 2, whereas in Grade 8, 65\% of struggling readers were boys (Torppa et al., 2015). Better reading skills of girls have been suggested to be due to a more positive attitude toward and interest in reading among girls than boys (e.g., OECD, 2010a). For example, Finnish girls participating in PISA Reading in 2009 reported enjoying reading more than boys did, girls spent notably more time on reading, and reported reading more diverse texts than boys (Brozo et al., 2014). Many studies have shown that reading comprehension correlates with leisure reading (Mol \& Bus, 2011; Torppa, Niemi, Vasalampi, Poikkeus, \& Lerkkanen, 2020), and, girls' more extensive voluntary reading could, thus, result in better reading comprehension.

Despite evidence of early differences in reading interest and other motivational factors favouring girls, the possibility remains that the gender gap in reading performance can be traced back to early language skills preceding learning to read. Gender differences favouring girls have been reported already in early language development (e.g., Berglund, Eriksson, \& Westerlund, 2005; Fenson et al., 1994). For instance, in a German study, girls aged 3-6 years were shown to have better language competence than boys (Lange et al., 2016). In addition, better early processing speed of English-speaking girls aged 4-7 years is suggested to contribute also to their better reading and writing skills (Palejwala \& Fine, 2015). In search for explanations for the gender difference in PISA Reading, it is important to examine whether gender differences in skills emerge already in Kindergarten when schooling-related factors do not yet have an influence.

\section{Summary of aims}

The aims of the study were as follows:

(1) to analyse the extent to which Kindergarten pre-reading skills-phonological awareness, rapid naming, letter knowledge, vocabulary, and listening comprehension-predict PISA Reading comprehension in Grade 9;

(2) to determine whether the predictive models are similar among boys and girls;

(3) to examine whether there are gender differences in the Kindergarten pre-reading skills. Provided that there are gender differences in the skills, the final aim is 
(4) to explore whether the gender difference in PISA Reading can be traced back to them that is, whether the gender-related difference in PISA Reading is fully mediated via the Kindergarten pre-reading skills.

\section{Methods}

\section{Participants}

The data of this study were drawn from a longitudinal study, the First Steps Study, (see Lerkkanen et al., 2006-2016) in which a community sample of about 2000 children were followed from Kindergarten to the end of Grade 9. Children were born in the year 2000 and came from four municipalities, two in Central Finland, one in Western Finland and one in Eastern Finland. Altogether 1839 children (873 girls; 966 boys) in the First Steps Study participated in Kindergarten assessments of prereading skills. Of the longitudinal sample, 1010 adolescents (480 girls; 530 boys) participated in the PISA Reading assessment in Grade 9. At the time of the Kindergarten assessments (spring 2006) the mean age of children was 6.1 years $(\mathrm{SD}=.29)$ and in the Grade 9 assessment (fall 2017) the average age was 15.3 years $(\mathrm{SD}=.33$ ). The First Steps Study has been reviewed by the University of Jyväskylä Ethical Committee. An informed written consent was given by the participants' parents (Kindergarten) and the participants themselves (Grade 9).

Because of attrition across time, we examined whether missingness was random. Little's MCAR test, $\chi^{2}(28)=86.85, p<.001$, suggested that the participants attending assessments in Grade 9 and in Kindergarten differed in some study measures from those not participating. The independent $t$ test comparisons of the two groups (participating vs. not participating in the Grade 9 assessment) in the Kindergarten skills are presented in Table 1 . The participants had slightly better Kindergarten performance in all assessed skills than the group of students not participating in Grade 9. However, the effect sizes were small (Table 1), reflecting the fact that attrition was mainly caused by children and their families moving away

Table 1 Comparison of children participating and not participating in the Grade 9 assessment with independent samples $t$ test

\begin{tabular}{|c|c|c|c|c|c|c|c|c|}
\hline \multirow[t]{2}{*}{ Kindergarten skills } & \multicolumn{3}{|c|}{$\begin{array}{l}\text { Participating in the } \\
\text { Grade } 9 \text { assessment }\end{array}$} & \multicolumn{3}{|c|}{$\begin{array}{l}\text { Not participating in the } \\
\text { Grade } 9 \text { assessment }\end{array}$} & \multirow[t]{2}{*}{$t$} & \multirow[t]{2}{*}{ Effect size $^{a}$} \\
\hline & $\mathrm{N}$ & Mean & SD & $\mathrm{N}$ & Mean & SD & & \\
\hline Phonological awareness & 1010 & 9.12 & 1.49 & 826 & 8.70 & 1.79 & $-5.06 * * *$ & .26 \\
\hline Rapid naming & 1010 & 69.10 & 15.81 & 825 & 71.74 & 19.84 & $3.10 * *$ & .15 \\
\hline Letter knowledge & 1010 & 23.93 & 6.02 & 826 & 22.33 & 7.17 & $-5.13 * * *$ & .24 \\
\hline Vocabulary & 1010 & 20.30 & 3.22 & 829 & 19.24 & 3.46 & $-6.76 * * *$ & .32 \\
\hline Listening comprehension & 1010 & 7.86 & 2.34 & 822 & 7.54 & 2.34 & $-2.92 * *$ & .14 \\
\hline
\end{tabular}

$* * p<.01 ; * * * p<.001$

${ }^{a}$ Effect sizes were estimated with Cohen's $d$ computed using pooled standard deviation 
from the study municipalities. Furthermore, the Grade 9 assessment did not include small classrooms with students having special needs. The participants of this study, $\mathrm{N}=1010$ (480 girls; 530 boys), had no missing data in any of the measures used in the analyses.

\section{Measures}

Kindergarteners' phonological awareness, rapid naming, letter knowledge, vocabulary and listening comprehension were assessed in April 2006 by trained testers in individual test sessions. Note that formal reading instruction starts in Finland in Grade 1, and the Kindergarten curriculum does not contain formal reading instruction (i.e., teaching of decoding or spelling), but kindergarteners are engaged in playful activities involving letters, words and numbers. Assessments were carried out by trained testers who were either university researchers or education or psychology graduate-stage students. Assessments in Grade 9 took place in November 2015 in the classrooms using group-administered tests.

\section{Phonological awareness}

The initial phoneme identification test (Lerkkanen, Poikkeus, \& Ketonen, 2006) included 10 items. In each of them the experimenter first named a row of four pictures of objects, gave the instruction "At the beginning of which word do you hear the sound/?/", and asked the child to point out the correct picture. All sounds were single phonemes. The score was the number of correct responses $(\max .=10)$. The Cronbach's alpha reliability coefficient was .76.

\section{Rapid naming}

Rapid naming of objects was assessed using the standard procedure (Denckla \& Rudel, 1976). The children were asked to name as fast as possible a series of five pictures of objects arranged in semi random order in five rows of 10 . There was a practice trial before the test to ensure the child's familiarity with names of the objects. The score was the total time in seconds that it took for the child to name all stimuli. Only a few errors occurred and for this reason, only total naming time was used in the analyses.

\section{Letter knowledge}

The children were asked to name all 29 Finnish letters which were shown on a sheet and arranged in three rows (Lerkkanen et al., 2006). The letters were named one row at the time, while the other rows were covered. The score was the number of correctly named letters $(\max .=29)$. The Cronbach's alpha reliability coefficient was .94. 


\section{Vocabulary}

Receptive language was assessed using a 30-item shortened version of the Peabody Picture Vocabulary Test-Revised (PPVT-R, Form L; Dunn \& Dunn, 1981). The children were asked to point out the picture from four alternatives which correctly represents the word spoken by the experimenter. The items for the shortened version were selected based on data from the full-scale administration of the PPVT-R in the Jyväskylä Longitudinal Study of Dyslexia (Lyytinen et al., 2004). The score was the number of correct responses $(\max .=30)$. The Cronbach's alpha reliability coefficient was .61.

\section{Listening comprehension}

Listening comprehension was assessed using a group-administered test developed at the Centre for Learning Research, University of Turku. The children heard a story with 130 words twice in the classroom setting after which they answered six multiple-choice questions (in four of the questions there were three choices, and in two questions there were four choices) which were based on the story and accompanied by pictures. The children were asked to select a picture that would best fit the story. Two points were given for each correct answer $(\max .=12)$. The Cronbach's alpha reliability coefficient was .30. Torppa et al. (2016) reported that the standardized beta for the prediction of another listening comprehension measure a year later was .45 .

\section{Programme for international student assessment reading}

The students had 60 min to complete the battery of reading tasks in the classroom group administered setting. These tasks formed the PISA Reading link items which are used repeatedly in each cycle of the PISA survey to ensure that the measurement remains comparable across time (OECD, 2010b). The booklet included eight different texts which students were asked to read and then answer questions. The reading materials consisted of texts, tables, graphs and figures. There were 15 multiple-choice questions and 16 questions, which required written responses. Of the questions, 12 required the students to access and retrieve information, 12 to integrate and interpret information and 7 to reflect and evaluate information. The total score was calculated by adding up the item scores (1 point given for each correct response). The maximum score was 31 . The Cronbach's alpha reliability coefficient was .75.

\section{Statistical Analysis}

First, the distributions of the measures were examined (see Table 2). Kindergarten vocabulary and listening comprehension approached the normal distribution. Phonological awareness and letter knowledge were left-skewed. Rapid naming was 
Table 2 Descriptive statistics of the measures

\begin{tabular}{lrrrrrrr}
\hline & N & Min & Max & Mean & SD & Skewness & Kurtosis \\
\hline PISA Reading & 1010 & 0 & 33 & 20.71 & 5.99 & -.62 & .15 \\
Phonological awareness & 1010 & 0 & 10 & 9.12 & 1.49 & -2.10 & 4.91 \\
Rapid naming & 1010 & 34 & 192 & 69.10 & 15.81 & 1.27 & 4.62 \\
Letter knowledge & 1010 & 0 & 29 & 23.93 & 6.02 & -1.49 & 1.63 \\
Vocabulary & 1010 & 8 & 29 & 20.30 & 3.23 & -.28 & -.03 \\
Listening comprehension & 1010 & 0 & 12 & 7.86 & 2.35 & -.36 & -.16 \\
\hline
\end{tabular}

somewhat right-skewed. One extreme outlier in rapid naming was moved to the end of the right-tail of the distribution. Due to the skewness of the measures, all path models were estimated using a robust maximum likelihood estimator (MLR) provided by Mplus 8.4 (Muthén \& Muthén, 1998-2017). Two types of path models were estimated. First, to examine if the Kindergarten skills predict Grade 9 PISA Reading similarly among boys and girls, multigroup models were estimated using within-gender standardized variables. The model estimates were compared between boys and girls by fixing each estimate equal one-by-one and examining the model fit. Second, to examine if the effect of gender on Grade 9 PISA Reading is direct or mediated via Kindergarten cognitive skills, a model where gender was set to predict reading comprehension both directly and indirectly via Kindergarten cognitive skills was estimated. The goodness-of-fit of the estimated models was evaluated using the following indicators: $\chi^{2}$-test, Comparative Fit Index (CFI), Root Mean Square Error of Approximation (RMSEA), and Standardized Root Mean Square Residual (SRMR). Good model fit is indicated by a small, preferably non-significant $\chi^{2}$, CFI > .95, RMSEA <.06, and SRMS <.08 (Hu \& Bentler, 1999).

\section{Results}

\section{Prediction of PISA Reading among boys and girls}

First, we examined the extent to which the Kindergarten skills predicted Grade 9 PISA Reading (RQ1) and whether the predictive models were similar among boys and girls (RQ2). Pearson correlation coefficients between the measures for boys and girls are presented in Table 3. All Kindergarten skills correlated significantly with the PISA Reading score for both genders. The multigroup path modeling (Fig. 1) suggested that the path from letter knowledge to PISA Reading was stronger for boys than girls as the model with equal path estimate did not fit the data well, $\chi^{2}(1)=5.04$, $p<.05$. All the other regression paths were equal for boys and girls. Furthermore, the correlations between phonological awareness and letter knowledge, vocabulary, and rapid naming as well as with letter knowledge and vocabulary were not equal for boys and girls (see Table 3). 
Table 3 Pearson correlation coefficients

\begin{tabular}{lrrrrrr}
\hline & 1. & 2. & 3. & 4. & 5. & 6. \\
\hline 1. PISA Reading & & $.19 * * *$ & $-.20 * * *$ & $.16^{* * *}$ & $.34 * * *$ & $.24 * * *$ \\
2. Phonological awareness & $.23 * * *$ & & $-.23 * * *$ & $.43 * * *$ & $.22 * * *$ & $.16^{* * * *}$ \\
3. Rapid naming & $-.27 * * *$ & $-.26 * * *$ & & $-.25 * * *$ & $-.13^{* *}$ & $-.12^{*}$ \\
4. Letter knowledge & $.33 * * *$ & $.54 * * *$ & $-.28 * * *$ & & $.14 * *$ & $.11^{*}$ \\
5. Vocabulary & $.32 * * *$ & $.18^{* * *}$ & $-.14 * *$ & $.21 * * *$ & $.31 * * *$ \\
6. Listening comprehension & $.22 * * *$ & $.16^{* * *}$ & -.05 & $.12 * *$ & $.32 * * *$ & \\
\hline
\end{tabular}

The coefficients for boys $(n=530)$ are below diagonal and for girls $(n=480)$ above diagonal $* p<.05 ; * * p<.01 ; * * * p<.001$

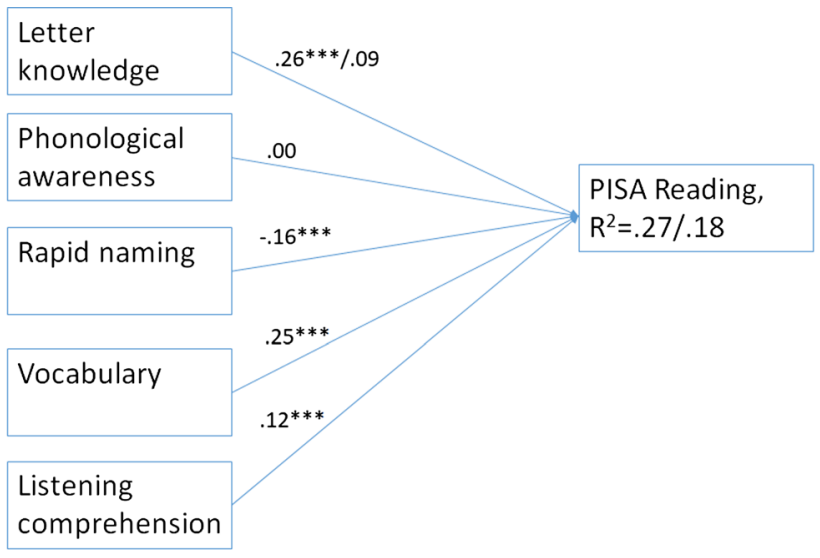

Kindergarten

Grade 9

Fig. 1 The final multigroup path model (single estimates when boys' and girls' estimates were equal and with separate estimates (boys/girls) for the path from letter knowledge where boys' and girls' estimates were not equal)

In the final model (Fig. 1), the path from letter knowledge to PISA Reading and the unequal correlations were freely estimated and the other paths and correlations were fixed equal for boys and girls. The model fitted the data well, $\chi^{2}(10)=4.84, p=.90, \mathrm{RMSEA}=.00, \mathrm{CFI}=1, \mathrm{SRMR}=.01$. In the model for boys, all kindergarten skills but phonological awareness predicted PISA Reading significantly, and $27 \%$ of the variance in PISA Reading was explained by the model. In the model for girls, rapid naming, vocabulary, and listening comprehension predicted PISA Reading, and $18 \%$ of the variance in PISA Reading was explained by the model. 
Table 4 Gender comparison with independent sample $t$ test

\begin{tabular}{|c|c|c|c|c|c|c|}
\hline & \multicolumn{2}{|c|}{$\begin{array}{l}\text { Boys } \\
\mathrm{N}=530\end{array}$} & \multicolumn{2}{|c|}{$\begin{array}{l}\text { Girls } \\
N=480\end{array}$} & \multirow[t]{2}{*}{$t$} & \multirow[t]{2}{*}{ Effect size $^{a}$} \\
\hline & Mean & SD & Mean & SD & & \\
\hline Phonological awareness & 8.93 & 1.61 & 9.33 & 1.33 & $-4.23 * * *$ & .27 \\
\hline Rapid naming & 69.97 & 17.20 & 68.14 & 16.40 & 1.84 & .11 \\
\hline Letter knowledge & 23.37 & 5.31 & 24.56 & 6.56 & $-3.17 * *$ & .20 \\
\hline Vocabulary & 20.52 & 3.27 & 20.05 & 3.16 & $2.29 *$ & .15 \\
\hline Listening comprehension & 7.82 & 2.32 & 7.90 & 2.38 & -.52 & .03 \\
\hline PISA Reading & 19.45 & 6.29 & 22.10 & 5.32 & $-7.25 * * *$ & .45 \\
\hline
\end{tabular}

$* p<.05 ; * * p<.01 ; * * * p<.001$

${ }^{a}$ Effect sizes were estimated with Cohen's $d$ computed using pooled standard deviation

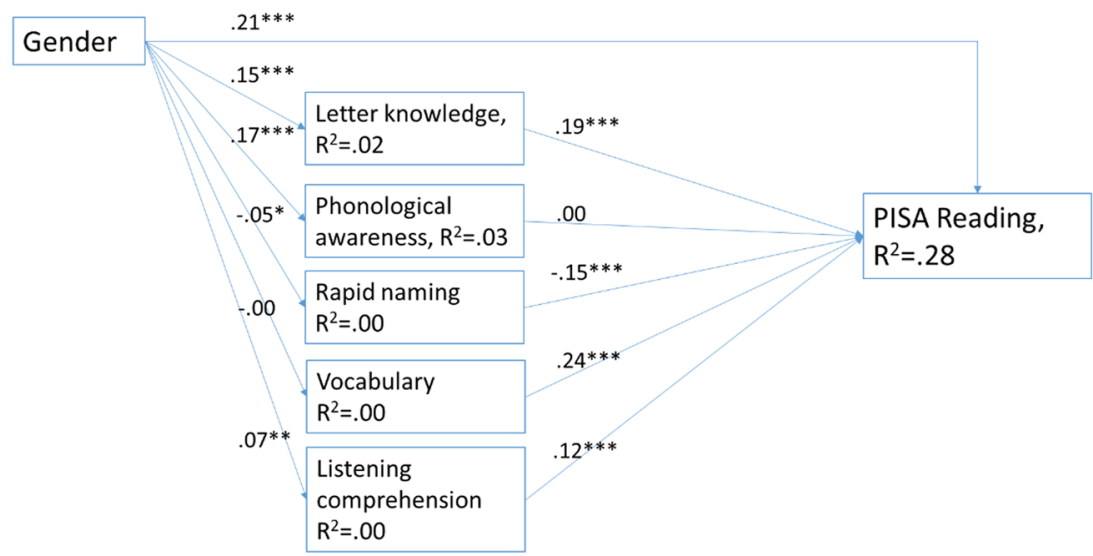

Kindergarten

Grade 9

Fig. 2 The mediator path model

\section{Mediation path models}

Second, we examined if there were gender differences in the kindergarteners' prereading skills (phonological awareness, rapid naming, letter knowledge, vocabulary, and listening comprehension) (RQ3), and if the gender-related differences in PISA Reading were fully mediated via these measures (RQ4). The descriptives, $t$ test results and effect sizes (Cohen's $d$ ) are reported in Table 4. Statistically significant gender differences emerged for the means of Kindergarten phonological awareness, letter knowledge, and vocabulary, and for Grade 9 PISA Reading. Girls outperformed boys in phonological awareness, letter knowledge, and PISA Reading while boys outperformed girls in vocabulary. The effect sizes were, however, either small or negligible except for PISA Reading performance, in which it 
was moderate (Cohen, 1992). Gender differences for rapid naming and listening comprehension were not statistically significant.

In the mediator path model (Fig. 2), of interest was if the effect of gender on PISA reading is mediated via the Kindergarten measures. The model predicted a total of $28 \%$ of the PISA Reading variance. The model suggested that the effect of gender on the PISA Reading score was mostly direct and only to a limited extent mediated via the Kindergarten skills. Three small but statistically significant indirect effects from gender to PISA Reading were identified and each one predicted 1-3\% of the PISA Reading score (altogether 5\%), one through letter knowledge (.03***), one through rapid naming $\left(.01^{*}\right)$, and one through listening comprehension $\left(.01^{*}\right)$. In other words, the gender differences in the Kindergarten skills did not fully explain the gender difference in the PISA Reading scores. The final model is saturated and thus no model fit indices are available.

\section{Discussion}

The aims of the present study were to examine the extent to which the Kindergarten pre-reading skills (phonological awareness, rapid naming, letter knowledge, vocabulary, and listening comprehension) among Finnish kindergarteners predict their PISA Reading comprehension performance at the age of 15 years. Moreover, we wanted to determine whether the predictive models are similar among boys and girls, whether there are gender differences in these Kindergarten pre-reading skills and whether the gender difference in PISA Reading can be explained by the prereading skills.

The Kindergarten pre-reading skills predicted $27 \%$ of the variance in reading comprehension assessed by the PISA Reading test among boys and $18 \%$ among girls. The finding is in accordance with earlier results in another, smaller Finnish sample with a high proportion of children with reading disability (Eklund et al., 2018). The same Kindergarten skills were significant predictors among both genders, except for letter knowledge, which was a significant predictor only for boys. The strong role of letter knowledge and rapid naming as significant predictors of reading comprehension 9 years later can be understood through their widely reported associations with reading fluency (e.g., Eklund et al., 2018; Georgiou et al., 2008; Kairaluoma et al., 2013; Savage \& Frederickson, 2005). The finding for letter knowledge extends previous literature by showing a long-term prediction of letter knowledge to early adolescence reading comprehension (e.g., Elbro et al., 1998; Pennington \& Lefly, 2001; Puolakanaho et al., 2007; Snowling, Gallagher, \& Frith, 2003). It is possible that letter knowledge was not a significant predictor among girls because their letter knowledge was already at a high level and there was too little variation at the end of Kindergarten. Rapid naming has been shown to be the best early predictor of reading fluency (e.g., Georgiou et al., 2008; Savage \& Frederickson, 2005; Torppa, Georgiou, Salmi, Eklund, \& Lyytinen, 2012) and it is likely that the effect of rapid naming on reading comprehension documented in the present study is mediated via reading fluency (e.g., Eklund et al., 2018; van Viersen et al., 2018). Prior findings attest that difficulties in rapid naming and letter knowledge predict persistent reading 
difficulties beyond early grades among Finnish readers (e.g., Eklund, Torppa, Aro, Leppänen, \& Lyytinen, 2015; Korhonen, 1995; Torppa et al., 2015). Although reading difficulties were not the focus of the present study, it is likely that a subgroup of the children with poor Kindergarten rapid naming and letter knowledge will become slow readers, which hampers reading comprehension, particularly when assessed using a measure with multiple texts like PISA Reading.

In addition to the known strong predictors of reading, letter knowledge and rapid naming, also Kindergarten vocabulary and listening comprehension predicted PISA Reading performance. This supports the findings of the previous studies on skills which are needed in PISA Reading (Arnbak, 2012) and of Kindergarten skills that predict reading comprehension during elementary grades (e.g., Eklund et al., 2018; Leppänen, Aunola, Niemi, \& Nurmi, 2008; Manolitsis et al., 2011; Torppa et al., 2016). Phonological awareness, on the other hand, did not add to the prediction which is in line with the previous similar findings in Finnish studies (e.g., Holopainen et al., 2001), and can be understood based on the nature of the Finnish language being situated at the far end of the continuum of transparency of orthography with almost perfect grapheme-phoneme correspondence and, consequently, kindergarteners being almost at the ceiling on initial phoneme identification.

The final aim of the present study was to examine whether the gender difference in favour of girls in PISA Reading can be explained by gender-related differences in pre-reading skills found in Kindergarten. As expected, a statistically significant gender difference in favour of girls emerged in PISA Reading which is in line with previous research on the gender gap in PISA Reading internationally (OECD, 2016) as well as in the Finnish context (Brozo et al., 2014; Vettenranta et al., 2016). In the national PISA Reading sample, the effect size for the gender difference was .50 (OECD, 2016) which is close to the effect size of .45 in the current sample. Quinn \& Wagner (2015), on the other hand, reported that boy:girl gender ratio at different levels of reading difficulties (percentiles 30, 15, 5, and 3) varies between 1.15-2.56:1 depending on reading measure and percentile. The gender ratios for PISA Reading percentiles in this sample were larger: 1.99:1 for percentile 30, 2.83:1 for percentile 15, 8.75:1 for percentile 5, and 7.67:1 for percentile 3. Quinn \& Wagner (2015) measures focused on reading fluency, however. These results suggest that gender differences are larger for PISA Reading comprehension than for reading fluency difficulties. With respect to gender differences in kindergarteners' pre-reading skills, we found that girls outperformed boys in phonological awareness and letter knowledge although the effect sizes suggested that the difference was small. The finding is in line with the previous studies reporting better pre-reading skills in Kindergarten for girls (Eklund et al., 2018; Lange et al., 2016; Palejwala \& Fine, 2015). Somewhat surprisingly, there were no differences in listening comprehension and boys outperformed girls in vocabulary, but the effect size was negligible. The findings are in general agreement with studies showing gender differences in reading-related skills and early reading (e.g., Berninger, Nielsen, Abbott, Wijsman, \& Radskind, 2008; Quinn \& Wagner, 2015; Stoet \& Geary, 2013).

The mediator model suggested that gender is a significant direct predictor of PISA Reading performance even after taking into account the effects of the Kindergarten skills. The effect of gender on PISA Reading was only partially 
mediated through letter knowledge, listening comprehension, and rapid naming explaining altogether $5 \%$ of the PISA Reading variance. The results thus suggest that the gender difference in PISA Reading do not derive from the Kindergarten pre-reading skills. Instead, our results call for other explanations, for example, girls getting more exposure to reading practice, reading more or broader types of texts compared to boys (Brozo et al., 2014), girls being more interested and engaged in reading (OECD, 2010a), or having a more favourable attitude toward reading in Grades 1-6 (McKenna, Kear, \& Ellsworth, 1995). In addition to the individual-level explanations in skills or motivation, also explanations at the level of cultural values, parenting practices, school environment factors, or pedagogical approaches are plausible (e.g., Stoet \& Geary, 2013).

The findings of the predictive analysis suggest that despite the many strengths of the Finnish education system, it does not fully alleviate or compensate for the differences in pre-reading skills existing between children in Kindergarten. In addition, the present findings also provide some support to the notion that the gender gap in reading tends to increase across the school years. As gender differences in reading comprehension mostly seem to develop during basic education, it is crucial that reading of boys would be supported more strongly in homes, schools, and in the society (see also Torppa et al., 2020). Notwithstanding the avid discussion on the gender gap in Finland, it is noteworthy that in an international comparison on average, also Finnish boys are good readers (e.g., OECD, 2016; Vettenranta et al., 2016). The debate rather reflects the egalitarian ethos of the Finnish comprehensive school; it is difficult to digest that an excellent reading performance seems to be associated with gender.

Certain limitations of the present study need to be considered. First, there was only one pre-reading measure per domain. A more extensive assessment might have yielded a stronger prediction. The assessment of listening comprehension in particular was not optimal as it was carried out in classrooms with only one task with few items. We cannot rule out the possibility that with more comprehensive measures, the mediation analysis of gender might have provided different results. Secondly, the measures of letter knowledge and phonological awareness were negatively skewed which is typical of Finnish kindergarteners. An earlier assessment would have yielded better psychometric properties but not necessarily a stronger predictive effects as also the gap between assessments would have increased. The Kindergarten assessment is also in alignment with the pedagogical practice in Finland. Thirdly, it is possible that readers with the poorest skills were underrepresented in the data because students in special-needs education classes were not included in the sample (however, children with special needs who attended regular classrooms were included). Fourthly, there was attrition in the sample. Students participating in the PISA Reading test had slightly better pre-reading skills in Kindergarten, albeit the effect sizes were small. The findings could be more robust if all students had participated in the Grade 9 assessment. In future research, other early predictors of PISA Reading performance should be considered, for example, kindergarteners' print exposure, motivational measures such as task-focused behaviour as well as school engagement during the elementary grades. 
In conclusion, considering the time-gap between the ages of 6 and 15 years, the amount of variance $(27 \% / 18 \%)$ of PISA Reading predicted by the Kindergarten prereading skills is remarkable. In Finland, schools as a rule provide uniformly highquality instruction by qualified teachers following the national core curriculum in collaboration with special needs teachers. Yet, close to a quarter of variance in reading comprehension scores at the age of 15 can be predicted by Kindergarten measures assessed prior to any reading instruction. This suggests some degree of stability in individual factors affecting reading development and, consequently, also the need for more careful early targeting of support. However, the gender-related gap in adolescent years appears to emerge along other pathways than differences in pre-reading skills related to gender. Therefore, the present results underscore the possibility that pathways of reading development through the school years appear to differ between girls and boys, much to the disadvantage of boys. If replicated across school systems, the findings would point up a profound challenge for the national curriculum.

Funding Open access funding provided by University of Jyväskylä (JYU). The study has been supported by grants from the Academy of Finland (Nos. 268586 2013-2017, 264264 2014-2017, 2762392014 2019, 292466 2015-2019, 263891 2013-2015, and 299506 2017-2019).

\section{Compliance with ethical standards}

Conflict of interest The author declares that they have no conflict of interest.

Open Access This article is licensed under a Creative Commons Attribution 4.0 International License, which permits use, sharing, adaptation, distribution and reproduction in any medium or format, as long as you give appropriate credit to the original author(s) and the source, provide a link to the Creative Commons licence, and indicate if changes were made. The images or other third party material in this article are included in the article's Creative Commons licence, unless indicated otherwise in a credit line to the material. If material is not included in the article's Creative Commons licence and your intended use is not permitted by statutory regulation or exceeds the permitted use, you will need to obtain permission directly from the copyright holder. To view a copy of this licence, visit http://creativecommons.org/licen ses/by/4.0/.

\section{References}

Arnbak, E. (2012). To what extent do basic skills predict students' PISA Reading score? In N. Egelund (Ed.), Northern Lights on PISA 2009: Focus on reading (pp. 75-89). TemaNord 2012:501. Nordic Council of Ministers.

Aro, M. (2017). Learning to read Finnish. In L. Verhoeven \& C. Perfetti (Eds.), Learning to read across languages and writing systems (pp. 416-436). Cambridge: Cambridge University Press.

Artelt, C., Schiefele, U., \& Schneider, W. (2001). Predictors of reading literacy. European Journal of Psychology of Education, 16(3), 363-383. https://doi.org/10.1007/BF03173188.

Bekebrede, J., van der Leij, A., \& Share, D. L. (2009). Dutch dyslexic adolescents: Phonological-core variable-orthographic differences. Reading and Writing: An Interdisciplinary Journal, 22(2), 133164. https://doi.org/10.1007/s11145-007-9105-7.

Berglund, E., Eriksson, M., \& Westerlund, M. (2005). Communicative skills in relation to gender, birth order, childcare and socioeconomic status in 18-month-old children. Scandinavian Journal of Psychology, 46(6), 485-491. https://doi.org/10.1111/j.1467-9450.2005.00480.x. 
Berninger, V. W., Nielsen, K. H., Abbott, R. D., Wijsman, E., \& Radskind, W. (2008). Gender differences in severity of writing and reading disabilities. Journal of School Psychology, 46(2), 151-172. https ://doi.org/10.1016/j.jsp.2007.02.007.

Brozo, W. G., Sulkunen, S., Shiel, G., Garbe, C., Pandian, A., \& Valtin, R. (2014). Reading, gender, and engagement: Lessons from five PISA countries. Journal of Adolescent \& Adult Literacy, 57(7), 584-593. https://doi.org/10.1002/jaal.291.

Cain, K. (2016). Reading comprehension and difficulties: An overview. Perspectives on Language and Literacy, 42(2), 9-16.

Cain, K., Oakhill, J., \& Bryant, P. (2004). Children's reading comprehension ability: Concurrent prediction by working memory, verbal ability, and component skills. Journal of Educational Psychology, 96(1), 31-42. https://doi.org/10.1037/0022-0663.96.1.31.

Cohen, J. (1992). A power primer. Psychological Bulletin, 112(1), 155-159. https://doi. org/10.1037/0033-2909.112.1.155.

de Jong, P. F., \& van der Leij, A. (2002). Effects of phonological abilities and linguistic comprehension on the development of reading. Scientific Studies of Reading, 6(1), 51-77. https://doi.org/10.1207/ S1532799XSSR0601_03.

Denckla, M. B., \& Rudel, R. G. (1976). Rapid “automatized” naming (R.A.N.): Dyslexia differentiated from other learning disabilities. Neuropsychologia, 14(4), 471-479. https://doi.org/10.1016/00283932(76)90075-0.

Dufva, M., Niemi, P., \& Voeten, M. (2001). The role of phonological memory, decoding, and comprehension skills in reading development: From preschool to grade 2. Reading and Writing: An Interdisciplinary Journal, 14(1-2), 91-117. https://doi.org/10.1023/A:1008186801932.

Dunn, L. M., \& Dunn, L. M. (1981). Peabody picture vocabulary test-Revised. American Guidance Service.

Eklund, K., Torppa, M., Aro, M., Leppänen, P. H. T., \& Lyytinen, H. (2015). Literacy skill development of children with familial risk for dyslexia through grades 2, 3, and 8. Journal of Educational Psychology, 107(1), 126-140. https://doi.org/10.1037/a0037121.

Eklund, K., Torppa, M., Sulkunen, S., Niemi, P., \& Ahonen, T. (2018). Early cognitive predictors of PISA Reading in children with and without family risk for dyslexia. Learning and Individual Differences, 64, 94-103. https://doi.org/10.1016/j.lindif.2018.04.012.

Elbro, C., Borstrøm, I., \& Petersen, D. K. (1998). Predicting dyslexia from kindergarten: The importance of distinctness of phonological representations of lexical items. Reading Research Quarterly, 33(1), 36-60. https://doi.org/10.1598/RRQ.33.1.3.

Fenson, L., Dale, P. S., Reznick, J. S., Bates, E., Thal, D. J., \& Pethick, S. J. (1994). Variability in early communicative development. Monographs of the Society for Research in Child Development, 59(5), i + iii-v + 1-185. https://doi.org/10.2307/1166093.

Florit, E., \& Cain, K. (2011). The simple view of reading: Is it valid for different types of alphabetic orthographies? Educational Psychology Review, 23(4), 553-576. https://doi.org/10.1007/s1064 8-011-9175-6.

Gallagher, A., Frith, U., \& Snowling, M. J. (2000). Precursors of literacy delay among children at genetic risk of dyslexia. Journal of Child Psychology and Psychiatry, 41(2), 203-213. https://doi. org/10.1111/1469-7610.00601.

Georgiou, G. K., Parrila, R., \& Papadopoulos, T. C. (2008). Predictors of word decoding and reading fluency across languages varying in orthographic consistency. Journal of Educational Psychology, 100(3), 566-580. https://doi.org/10.1037/0022-0663.100.3.566.

Gough, P. B., \& Tunmer, W. E. (1986). Decoding, reading, and reading disability. RASE: Remedial \& Special Education, 7(1), 6-10. https://doi.org/10.1177/074193258600700104.

Holopainen, L., Ahonen, T., \& Lyytinen, H. (2001). Predicting delay in reading achievement in a highly transparent language. Journal of Learning Disabilities, 34(5), 401-413. https://doi. org/10.1177/002221940103400502.

Hoover, W. A., \& Gough, P. B. (1990). The simple view of reading. Reading and Writing: An Interdisciplinary Journal, 2(2), 127-160. https://doi.org/10.1007/BF00401799.

Hu, L. T., \& Bentler, P. M. (1999). Cutoff criteria for fit indexes in covariance structure analysis: Conventional criteria versus new alternatives. Structural Equation Modeling: A Multidisciplinary Journal, 6(1), 1-55. https://doi.org/10.1080/10705519909540118.

Jimenez, J. E., de Garcia, L. C., Siegel, L. S., O’Shanahan, I., Garcia, E., \& Rodriguez, C. (2011). Gender ratio and cognitive profiles in dyslexia: A cross-national study. Reading and Writing: An Interdisciplinary Journal, 24(7), 729-747. https://doi.org/10.1007/s11145-009-9222-6. 
Kairaluoma, L., Torppa, M., Westerholm, J., Ahonen, T., \& Aro, M. (2013). The nature of and factors related to reading difficulties among adolescents in a transparent orthography. Scientific Studies of Reading, 17(5), 315-332. https://doi.org/10.1080/10888438.2012.701257.

Kirby, J. R., \& Savage, R. S. (2008). Can the simple view deal with the complexities of reading? Literacy, 42(2), 75-82. https://doi.org/10.1111/j.17414369.2008.00487.x.

Korhonen, T. T. (1995). The persistence of rapid naming problems in children with reading disabilities: A nine-year follow-up. Journal of Learning Disabilities, 28(4), 232-239. https://doi. org/10.1177/002221949502800405.

Landerl, K., \& Wimmer, H. (2000). Deficits in phoneme segmentation are not the core problem of dyslexia: Evidence from German and English children. Applied Psycholinguistics, 21(2), 243-262. https://doi.org/10.1017/S0142716400002058.

Lange, B. P., Euler, H. A., \& Zaretsky, E. (2016). Sex differences in language competence of 3- to 6-yearold children. Applied Psycholinguistics, 37(6), 1417-1438. https://doi.org/10.1017/S014271641 5000624.

Leppänen, U., Aunola, K., Niemi, P., \& Nurmi, J.-E. (2008). Letter knowledge predicts grade 4 reading fluency and reading comprehension. Learning and Instruction, 18(6), 548-564. https://doi. org/10.1016/j.learninstruc.2007.11.004.

Lerkkanen, M.-K., Niemi, P., Poikkeus, A.-M., Poskiparta, E., Siekkinen, M., \& Nurmi, J.-E. (20062016). Alkuportaat [First Steps Study]. University of Jyväskylä, University of Turku, and University of Eastern Finland. Retrieved from www.jyu.fi/alkuportaat.

Lerkkanen, M.-K., Poikkeus, A.-M., \& Ketonen, R. (2006). ARMI-Luku-ja kirjoitustaidon arviointimateriaali 1. luokalle [ARMI-A tool for assessing reading and writing skills in Grade 1]. WSOY.

Lerkkanen, M.-K., Rasku-Puttonen, H., Aunola, K., \& Nurmi, J.-E. (2004). Predicting reading performance during the first and the second year of primary school. British Educational Research Journal, 30(1), 67-92. https://doi.org/10.1080/01411920310001629974.

Lyytinen, H., Aro, M., Eklund, K., Erskine, J., Guttorm, T., Laakso, M.-L., et al. (2004). The development of children at familial risk for dyslexia: Birth to early school age. Annals of Dyslexia, 54(2), 184-220. https://doi.org/10.1007/s11881-004-0010-3.

Manolitsis, G., Georgiou, G. K., \& Parrila, R. (2011). Revisiting the home literacy model of reading development in an orthographically consistent language. Learning and Instruction, 21(4), 496-505.

McGeown, S., Goodwin, H., Henderson, N., \& Wright, P. (2012). Gender differences in reading motivation: Does sex or gender identity provide a better account? Journal of Research in Reading, 35(3), 328-336. https://doi.org/10.1111/j.1467-9817.2010.01481.x.

McKenna, M. C., Kear, D. J., \& Ellsworth, R. A. (1995). Children's attitudes toward reading: A national survey. Reading Research Quarterly, 30(4), 934-956. https://doi.org/10.2307/748205.

Mol, S. E., \& Bus, A. G. (2011). To read or not to read: A meta-analysis of print exposure from infancy to early adulthood. Psychological Bulletin, 137(2), 267-296. https://doi.org/10.1037/a0021890.

Moll, K., Kunze, S., Neuhoff, N., Bruder, J., \& Schulte-Körne, G. (2014). Specific learning disorder: Prevalence and gender differences. PLOS ONE, 9(7), e103537. https://doi.org/10.1371/journ al.pone.0103537.

Muthén, L. K., \& Muthén, B. O. (1998-2017). Mplus user's guide (8th ed.). https://www.statmodel.com/ download/usersguide/MplusUserGuideVer_8.pdf.

OECD. (2010a). PISA 2009 results: Learning to learn: Student engagement, strategies and practices (Vol. III). Paris: OECD Publishing. https://doi.org/10.1787/9789264083943-en.

OECD. (2010b). PISA 2009 results: Learning trends: Changes in student performance since 2000 (Vol. V). Paris: OECD Publishing. https://doi.org/10.1787/9789264091580-en.

OECD. (2014). PISA 2012 results: What students know and can do: Student performance in mathematics, reading and science (Revised ed., Vol. I). Paris: OECD Publishing. https://doi.org/10.1787/97892 64201118-en.

OECD. (2016). PISA 2015 results (Volume I): Excellence and equity in education. Paris: OECD Publishing. https://doi.org/10.1787/9789264266490-en.

OECD. (2017a). What is PISA? In: PISA 2015 assessment and analytical framework: Science, reading, mathematic, financial literacy and collaborative problem solving. OECD Publishing. https://doi. org/10.1787/9789264281820-4-en.

OECD. (2017b). PISA Reading framework. In: PISA 2015 assessment and analytical framework: Science, reading, mathematic, financial literacy and collaborative problem solving. OECD Publishing. https://doi.org/10.1787/9789264281820-4-en. 
Ouellette, G. P. (2006). What's meaning got to do with it: The role of vocabulary in word reading and reading comprehension. Journal of Educational Psychology, 98(3), 554-566. https://doi. org/10.1037/0022-0663.98.3.554.

Palejwala, M. H., \& Fine, J. G. (2015). Gender differences in latent cognitive abilities in children aged 2-7. Intelligence, 48, 96-108. https://doi.org/10.1016/j.intell.2014.11.004.

Pennington, B. F., \& Lefly, D. L. (2001). Early reading development in children at family risk for dyslexia. Child Development, 72(3), 816-833. https://doi.org/10.1111/1467-8624.00317.

Perfetti, C. A. (1985). Reading ability. Oxford: Oxford University Press.

Puolakanaho, A., Ahonen, T., Aro, M., Eklund, K., Leppänen, P. H. T., Poikkeus, A.-M., et al. (2007). Very early phonological and language skills: Estimating individual risk of reading disability. Journal of Child Psychology and Psychiatry, 48(9), 923-931. https://doi.org/10.111 1/j.1469-7610.2007.01763.x.

Quinn, J. M. (2018). Differential identification of females and males with reading difficulties: A metaanalysis. Reading and Writing: An Interdisciplinary Journal, 31(5), 1039-1061. https://doi. org/10.1007/s11145-018-9827-8.

Quinn, J. M., \& Wagner, R. K. (2015). Gender differences in reading impairment and in the identification of impaired readers: Results from a large-scale study of at-risk readers. Journal of Learning Disabilities, 48(4), 433-445. https://doi.org/10.1177/0022219413508323.

Savage, R. S., \& Frederickson, N. (2005). Evidence of a highly specific relationship between rapid automatic naming of digits and text reading speed. Brain and Language, 93(2), 152-159. https://doi. org/10.1016/j.bandl.2004.09.005.

Snowling, M. J., Gallagher, A., \& Frith, U. (2003). Family risk of dyslexia is continuous: Individual differences in the precursors of reading skills. Child Development, 74(2), 358-373. https://doi. org/10.1111/1467-8624.7402003.

Stoet, G., \& Geary, D. C. (2013). Sex differences in mathematics and reading achievement are inversely related: Within- and across-nation assessment of 10 years of PISA data. PLoS ONE, 8(3), e57988. https://doi.org/10.1371/journal.pone.0057988.

Torppa, M., Eklund, K., Sulkunen, S., Niemi, P., \& Ahonen, T. (2018). Why do boys and girls perform differently on PISA Reading in Finland? The effects of reading fluency, achievement behaviour, leisure reading and homework activity. Journal of Research in Reading, 41(1), 122-139. https://doi. org/10.1111/1467-9817.12103.

Torppa, M., Eklund, K., van Bergen, E., \& Lyytinen, H. (2015). Late-emerging and resolving dyslexia: A follow-up study from kindergarten to Grade 8. Journal of Abnormal Child Psychology, 43(7), 1389-1401. https://doi.org/10.1007/s10802-015-0003-1.

Torppa, M., Georgiou, G. K., Lerkkanen, M.-K., Niemi, P., Poikkeus, A.-M., \& Nurmi, J.-E. (2016). Examining the simple view of reading in a transparent orthography: A longitudinal study from kindergarten to grade 3. Merrill-Palmer Quarterly, 62(2), 179-206. https://doi.org/10.13110/merrp almquar1982.62.2.0179.

Torppa, M., Georgiou, G., Salmi, P., Eklund, K., \& Lyytinen, H. (2012). Examining the double-deficit hypothesis in an orthographically consistent language. Scientific Studies of Reading, 16(4), 287315. https://doi.org/10.1080/10888438.2011.554470.

Torppa, M., Niemi, P., Vasalampi, K., Poikkeus, A.-M., \& Lerkkanen, M.-K. (2020). Leisure reading (but not any kind) and reading comprehension support each other-A longitudinal study across Grades 1 and 9. Child Development, 91, 876-900. https://doi.org/10.1111/cdev.13241.

Torppa, M., Tolvanen, A., Poikkeus, A.-M., Eklund, K., Lerkkanen, M.-K., Leskinen, E., et al. (2006). Reading development subtypes and their early characteristics. Annals of Dyslexia, 57(1), 3-32. https ://doi.org/10.1007/s11881-007-0003-0.

van Viersen, S., de Bree, E. H., Zee, M., Maassen, B., van der Leij, A., \& de Jong, P. F. (2018). Pathways into literacy: The role of early oral language abilities and family risk for dyslexia. Psychological Science, 29(3), 418-428. https://doi.org/10.1177/2F0956797617736886.

Vettenranta, J., Välijärvi, J., Ahonen, A., Hautamäki, J., Hiltunen, J., Leino, K., et al. (2016). PISA 15 Ensituloksia. Huipulla pudotuksesta huolimatta (First results. At the top despite of the fall). Helsinki: Publications of Ministry of Education and Culture, 2016:41. http://julkaisut.valtioneuvosto.fi/ bitstream/handle/10024/79052/okm41.pdf.

Ziegler, J. C., Bertrand, D., Tóth, D., Csépe, V., Reis, A., Faísca, L., et al. (2010). Orthographic depth and its impact on universal predictors of reading: A cross-language investigation. Psychological Science, 21(4), 551-559. https://doi.org/10.1177/0956797610363406. 
Publisher's Note Springer Nature remains neutral with regard to jurisdictional claims in published maps and institutional affiliations.

\section{Affiliations}

Mari Manu' ${ }^{1} \cdot$ Minna Torppa $^{1}\left(\mathbb{D} \cdot\right.$ Kenneth Eklund $^{2} \oplus$.

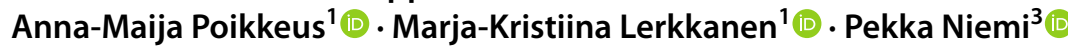

1 Department of Teacher Education, University of Jyvaskyla, P.O. Box 35, 40014 Jyvaskyla, Finland

2 Faculty of Education and Psychology, University of Jyvaskyla, P.O. Box 35, 40014 Jyvaskyla, Finland

3 Department of Psychology, University of Turku, 20014 Turku, Finland 